\title{
Fontes do messianismo milenarista brasileiro
}

Antônio Maspoli de Araújo Gomes

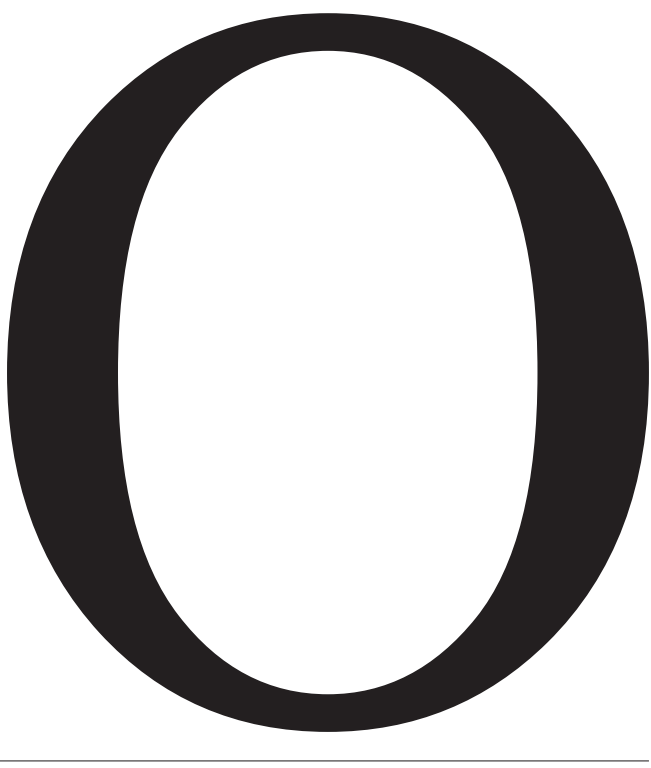

ESTUDOS SOBRE 0 MESSIANISMO MILENARISTA NO BRASIL

fenômeno religioso messiânico-milenarista vem sendo pesquisado no Brasil desde meados do século XIX. Inicialmente explicado a partir de interpretações biopsicológicas e ambientalistas com Nina Rodrigues (2006), Euclides da Cunha (1966), Josué de Castro (1965, s/d), dentre outros, posteriormente passou a ser interpretado a partir de variáveis

Pesquisa realizada sob a orientação do prof. dr. João Baptista Borges Pereira no Programa de Pós-Doutorado em Antropologia da Religião da Universidade Presbiteriana Mackenzie, com bolsa do Mackpesquisa. 
sociológicas, em uma concepção do materialismo dialético, mormente com Rui Facó (1976), na obra Cangaceiros e fanáticos, e Maria Isaura Pereira de Queiroz (1976), que elaborou uma tipologia desses movimentos. Importante também tem sido a contribuição de Renato Queiroz (1995) para compreender o fenômeno milenarista contemporâneo, como, por exemplo, o fenômeno de Catulé.

Diversos autores escreveram sobre os messianismos. Aqui citaremos apenas alguns. José Lins do Rego (1939) e Rubim Santos Leão de Aquino (2006), dentre outros, contaram a história de Pedra Bonita; Douglas Teixeira Monteiro (1974) e Paulo Pinheiro Machado (2006) estudaram o Contestado; Euclides da Cunha (1966) descreveu Canudos; Lopes (1991) pesquisou o Caldeirão; Monteiro (1977) estudou Juazeiro do Norte; Renato Silva Queiroz (1995) pesquisou o Catulé; Eleonora Zicari Costa de Brito (2006) escreveu Santa Dica, a santa ressuscitada de Goiás; e Cláudia Mentz Martins (2006) escreveu Os Muckers, os fiéis armados de Jacobina. Mais recentemente, foi publicada a obra Os Aves de Jesus em Juazeiro do Norte (Carneiro \& Martins, 2006).

O messianismo milenarista brasileiro foi revisitado recentemente por outros autores em um importante dossiê publicado nesta Revista USP. Rodrigo Franklin de Sousa (2009) escreveu sobre "O desenvolvimento histórico do messianismo judaico antigo: diversidade e coerência". Márcio Honório de Godoy (2009) demonstrou novas nuances do sebastianismo no texto "O desejado e o encoberto: potências de movimento de um mito andarilho". Lísias Nogueira Negrão (2009) contribui para a reinvenção dos messianismos e milenarismos brasileiros com seu ensaio "Sobre os messianismos e milenarismos brasileiros". Walnice Nogueira Galvão (2009) revisitou o messianismo euclidiano no texto "Euclides da Cunha, precursor". Antonio Máspoli de Araújo Gomes (2009) contribui para a compreensão do conflito religioso do Caldeirão de Santa Cruz do Deserto com o relato de uma pesquisa de campo sobre o tema. Cristina Pompa (2009) lançou novas luzes sobre o Pau de Colher. Celso Vianna Bezerra de Menezes (2009) esclareceu novos aspectos sobre a religião de Contestado, no artigo "Rituais de devoção: os herdeiros do milenarismo de Contestado". Renato da Silva Queiroz (2009) faz novas incursões sobre o messianismo de Catulé no texto "O demônio e o messias: notas sobre o surto sociorreligioso do Catulé". Heloísa Mara Luchesi Módulo (2009) faz uma leitura psicológica dos Muckers. Julio Cezar Melatti (2009) apresenta uma pesquisa sobre o messianismo entre os craôs do norte de Goiás.

Esses movimentos messiânico-milenaristas foram pesquisados a partir das variáveis histórico-sociais sem, contudo, considerar a importância da religião, dos símbolos, mitos e ritos, para a consecução da construção do imaginário dessas comunidades em tais eventos. Maria Isaura Pereira de Queiroz (1976) destaca-se no Brasil pelas pesquisas no campo do fenômeno do messianismo. A autora, contudo, deixa claro na introdução da sua obra que a esfera do seu trabalho será o conflito social como base para os movimentos messiânicos milenaristas. Para ela, o conflito social é entendido como o choque entre o latifúndio e as populações sem terra, marginalizadas e empobrecidas. O sagrado apontado como um dos fatores preexistentes para a ocorrência desse fe- 
nômeno não é considerado. Essa pesquisa, portanto, busca analisar as contribuições da religião para a construção daquilo que se convencionou chamar de o messianismo milenarista brasileiro.

Fenômenos como Canudos, Contestado, Pedra Bonita e Caldeirão foram pesquisados sob diversos aspectos: político, militar, social, econômico, etc. No entanto, esses fatos ainda não foram considerados sob a perspectiva da variável religiosa. A questão religiosa quase sempre foi deixada de lado nas pesquisas, como algo de somenos importância, seja pela falta de espaço na academia para pesquisas dessa natureza, seja pela exiguidade de pesquisadores interessados nesse tema. "O único ponto talvez que comportaria ainda desenvolvimento seria o aspecto religioso do messianismo (que a autora não abordou, pois preferiu se colocar na perspectiva sociológica que o trabalho apresenta)" (Bastide, 1976, p. XX).

A análise desses fenômenos, sob a perspectiva da religião, pode contribuir para compreender importantes movimentos sociais ocorridos no Brasil em meados do século XIX e na primeira metade do século XX, como, por exemplo, a relação entre o êxodo rural e o novo messianismo.

"O imaginário religioso pregresso, sua exacerbação ou superação por uma nova revelação profética, está sempre presente, interpretando a realidade, postulando objetivos e indicando os meios pelos quais estes serão alcançados" (Negrão, 2009, p. 34).

A esperança messiânica, a espera de um messias, a ânsia por uma terra prometida, por um paraíso perdido, é uma matriz mítica de conteúdo arquetípico que aparece no imaginário religioso de quase todos os povos. Nos povos ocidentais, cujas raízes mergulham nas próprias origens do pensamento judaico-cristão, a esperança messiânica concretiza-se na espera de entes messiânicos, um messias, na vivência de um tempo messiânico, o kairós do messias (no tempo messiânico) e na delimitação de um espaço messiânico, a terra prometida.

"Os mestres da suspeita - Marx e Nietzsche particularmente - esforçaram-se para desmascarar as ciladas da alienação. Será a esperança - como a religião - a atitude do homem que ainda não se encontrou ou então já se perdeu novamente?” (Desroche, 1985, p. 40.)

\section{FONTES LUSITANAS DO MESSIANISMO E MILENARISMO BRASILEIRO}

A religião de Israel é uma religião messiânica. O Antigo Testamento transborda de esperança messiânica. A esperança messiânica aponta para o horizonte escatológico do reino messiânico de Deus, o reino escatológico do shalom, no qual reinará o Príncipe da Paz. Esse reino deveria ser decorrência natural de um mundo ordenado por Deus, em uma terra prometida, cujo resultado é a prática da justiça entre os homens. Nesse reino, as promessas escatológicas deveriam se transformar em esperança criativa visto que somos mais que intérpretes do futuro; somos colaboradores com Deus na criação do futuro (Van Groningen, 2003, pp. 497-591). Essa afirmação encontra seu fundamento na profecia messiânica de Isaías: "Porque um menino nos nasceu, um filho se nos deu; e o governo estará sobre os seus ombros; e o seu 
nome será: Maravilhoso Conselheiro, Deus Forte, Pai Eterno, Príncipe da Paz" (Isaías 9:1-6). Os profetas não previram objetivamente a vinda de Jesus. Eles anunciaram genericamente a vinda de um rei justo e bom, um messias, da descendência de Davi. Já os autores e os intérpretes do Novo Testamento viram em Jesus a realização da esperança messiânica. Essa interpretação é negada pelo judaísmo e seguida pelo cristianismo em todas as suas vertentes.

O Príncipe da Paz é a garantia do shalom. O shalom é o resgate da ordem justa do mundo criado por Deus. Na linguagem bíblica, essa nova ordem é conhecida também como Reino de Deus - o sonho do mundo bom, recuperado. O shalom é o conteúdo do reino messiânico, pois é ele, o Príncipe da Paz, quem estabelece o shalom. O shalom está totalmente relacionado à justiça; isto é, para alcançar o shalom é necessário praticar a justiça. Nos dicionários de língua portuguesa, a justiça aparece sempre muito restrita à esfera do direito legal e com forte ênfase nos direitos individuais. Percebe-se uma forte influência da concepção romana de justiça com base nas leis e na filosofia grega, que enfatizam os direitos do cidadão (Van Groningen, 2003, pp. 497-591). Rodrigo Franklin de Sousa (2009, p. 10) oferece as bases para uma exegese bíblica desse termo:

"O termo 'messias' deriva do grego 'messias', que por sua vez deriva do aramaico 'mashiha' e do hebraico 'mashiach' ('ungido'). O termo grego aparece no Evangelho de João 1:42; 4:25 de forma a indicar que, no período da escrita do Novo Testamento, já se inseria no contexto de um discurso com o qual pelo menos uma parcela da população judaica já se encontrava familiarizada".
Walnice Nogueira Galvão (2009, p. 52) aponta para a existência desses elementos do messianismo bíblico na obra Os sertões, de Euclides da Cunha. Diz ela:

"Isso se efetiva através da mimese do grande sintagma narrativo da Bíblia, por meio do qual é traçado o arco que vai da criação do arraial de Canudos, o Gênese bíblico, até seu aniquilamento pelo 'fogo', o Apocalipse, em conjunção com as profecias das sagradas escrituras".

A hermenêutica sertaneja, fincada em pressupostos do catolicismo popular e das crendices próprias do sertão, faz uma interpretação particular do sentido bíblico do messias e dos termos messiânicos.

"O Rio da Água da Vida que corre no Paraíso não é mais que o rio seco que passa por Canudos, o Vaza-Barris. A Árvore da Vida se transforma na árvore da morte. E assim sucessivamente. Essa era a visão dos canudenses, que Euclides soube captar, informar literariamente e expressar" (Galvão, 2009, p. 53).

Outro mito importante na construção do messianismo brasileiro é aquele da crença indígena da Terra sem Males. O messianismo indígena brasileiro autóctone ou fruto do choque com o cristianismo é por demais conhecido. Esse messianismo mais antigo se expressa pelo mito da Terra sem Males e mais recentemente pelo profetismo (Lanternari, 1974, pp. 187-9; Melatti, 2009). Os índios, pressionados pelo avanço da colonização europeia, especialmente a população guarani que permaneceu fora das reduções e do âmbito de ação de encomendeiros e 
bandeirantes, foram sendo paulatinamente empurrados para as matas adjacentes ao Rio Paraná. Outros se deslocaram em direção ao centro do país e do litoral atlântico em busca da Terra sem Males.

"Segundo notícias dadas por Curt Nimuendajú, a migração dos tupis para o oriente devia-se ao objetivo que eles perseguiam de encontrar uma terra sem males, pela qual os nativos teriam abandonado as regiões originárias do interior antes da chegada dos portugueses" (Lanternari, 1974, p. 190).

A Terra sem Males, a versão indígena do Paraíso Perdido, era um lugar destinado ao herói fundador da tribo, ao pagé, ao xamã, ao guerreiro e ao homem simples que havia bem servido ao seu povo. Um lugar de fartura, de abundância, de paz. Aquele lugar onde o sofrimento encontra o seu fim e a felicidade toma conta. Lá os inimigos fugirão, a velhice será transformada em juventude e a morte dará lugar à vida (Lanternari, 1974, p. 191). O paralelo da Terra sem Males com a narrativa do Apocalipse é perfeito.

"E ali não haverá mais noite, e não necessitarão de luz de lâmpada nem de luz do sol, porque o Senhor Deus os alumiará; e reinarão pelos séculos dos séculos. E disse-me: Estas palavras são fiéis e verdadeiras; e o Senhor, o Deus dos espíritos dos profetas, enviou o seu anjo, para mostrar aos seus servos as coisas que em breve hão de acontecer" (Apocalipse 22:1- 6).

Além do mito da Terra sem Males temos a influência de Joaquim de Flora na construção do messianismo milenarista brasileiro. $\mathrm{O}$ surto messiânico milenarista que eclodiu no
Brasil, em meados do século XIX e primeira metade do século $\mathrm{XX}$, remonta suas origens às pregações em Influência de Joaquim de Flora em Portugal e na Europa (Franco \& Mourão, 2005). Joaquim de Flora (1130/351202), teólogo contemplativo da Ordem de Cluny, foi um dos mais influentes espíritos do século que marcou o nascimento da figura do intelectual e das universidades. A originalidade dos seus escritos deve-se, sobretudo, à preeminência que dá, no livro Concórdia nova, ao Espírito Santo, relativamente ao Pai (Idade dos Anciãos) e a Jesus Cristo (Idade dos Jovens). As duas primeiras idades correspondiam aos tempos primordiais da humanidade e à era de Cristo. Esse ponto de vista transgredia a concepção comumente aceita de que o Gênesis bíblico correspondia a um Paraíso terrestre em que o homem e a mulher (Adão e Eva) tinham sido perfeitos e, por isso, felizes, até a queda pecaminosa que os fizera perder a pureza que era própria da sua grande espiritualidade (Franco \& Mourão, 2005).

Joaquim de Flora assim acreditava que o Antigo Testamento subsistia no Novo Testamento especialmente quanto à literatura apocalíptica. Ele acreditava que o Novo Testamento já subsistia em germe no Velho Testamento e que esse existia como fruto no Novo Testamento. Seu pensamento interpretava de forma alegórica o Apocalipse de João; suas profecias propalavam a abertura do Sétimo Selo desse livro, o que se concretizava na manifestação visível do reino de Deus (Apocalipse 7:1; 9:21). A chave para a interpretação do Livro do Apocalipse lhe fora concedida por meio de uma visão celestial (Franco \& Mourão, 2005, p. 16; Löwith, 1991, pp. 140-50). “A partir dessa concepção exegética Joaquim 
de Flora constrói uma teologia da história e formula a utopia da Idade do Espírito Santo, além de reconstituir a crítica socioeclesial que esta figura sofreu" (Baltazar, 2006, pp. 1-3).

No entanto, a influência mais importante de Joaquim de Flora na cultura portuguesa será na criação e estabelecimento das Festas do Divino, precursoras do estabelecimento do Império do Divino, império este baseado nas idades escatológicas do mundo que, no joaquinismo, é a base para a construção do pensamento escatológico milenarista dispensacionalista que tomou conta do protestantismo fundamentalista norte-americano e de seus descendentes no mundo moderno.

"Em síntese, podemos dizer que a doutrina joaquimita condensa em seu interior muitos aspectos básicos da reflexão escatológica judaico-cristã, em especial no que se refere aos períodos e cifras nos quais se pode dividir a história" (Dobroruka, 2009).

A importância da sucessão dessas idades é que, de uma era à outra, a visão da Trindade ia se esclarecendo. Daí a imagem famosa de suas três idades do mundo representadas analogamente às horas do dia: a primeira, identificada com o Antigo Testamento e a lei mosaica, sob a luz das estrelas; a segunda, análoga ao Novo Testamento e encarnada pela Igreja de Roma, como a aurora; e a vindoura, que seria definida por uma nova "Igreja espiritual", como sendo o dia claro. As três idades do mundo estão ainda identificadas com as três pessoas da Trindade, sendo a primeira do Pai, a segunda do Filho e a terceira do Espírito Santo (Dobroruka, 2009, pp. 14-6).
"A história da salvação inserida na história da humanidade confere ao Homem um sentido completo: eis a grande contribuição de Joaquim de Flora. Também os movimentos religiosos reformistas modernos ou os teorizadores das utopias universalistas descendem do abade calabrês" (Baltazar, 2006, pp. 1-3).

No Brasil, o pensamento de Joaquim de Flora deu origem à Folia do Divino, um conjunto de festas dedicadas ao Império do Divino Espírito Santo. Essas festas e bailados foram transplantados de Portugal para o Brasil e aqui ganharam a simpatia e adesão das populações mais pobres e marginalizadas. O Império do Divino seria para essas populações a manifestação visível do reino de Deus na terra (Saint-Hilaire apud Cascudo, 1927, pp. 83-4).

Joaquim de Flora foi seguido por Gonçalo Annes, o Bandarra, (Magalhães, 2004). Bandarra nasceu em torno de 1500 na cidade de Trancoso. Desenvolve a profissão de lambedor de sola, como era conhecido o sapateiro. É um trovador nato. Compõe trovas messiânico-milenaristas, nas quais apresenta o rei de Portugal como o messias, o Desejado de Todas as Nações. A Igreja o persegue, o acusa de heresia em 1541. É julgado pelo Tribunal do Santo Ofício e condenado a uma pena leve. Retorna a Trancoso, onde vem a falecer em 1556.

Em 1603, as "trovas do Bandarra", como ficaram conhecidos seus escritos, são impressas pela primeira vez, em Paris, por obra de D. João de Castro (com o título pomposo de Paráfrase e concordância de algumas profecias de Bandarra, sapateiro de Trancoso). Em 1644 as trovas são publicadas pela segunda vez, em Nantes. Em 1809, são reeditadas em Barcelona, por ocasião das 
invasões francesas. As trovas de Bandarra não só atualizaram as profecias de Joaquim de Flora como lançaram as bases para o sebastianismo (Magalhães, 2004). Hermann (1996, p. 12) vincula as trovas de Bandarra às origens do sebastianismo:

"Assim como os demais autores citados, Hermann trata as trovas como elemento de explicação do sebastianismo, seguindo os passos dados até então, ao tratar as reapropriações e releituras das trovas de Bandarra e sua importância para a constituição do messianismo sebástico" (Magalhães, 2004, pp. 15-6).

O catolicismo popular português tem suas peculiaridades. Se, por um lado, é marcado por um afastamento de Roma, por outro, é marcado pela crença na iluminação direta. Deus fala diretamente com o seu povo sem a mediação da Igreja e sem a necessidade da revelação especial, a Bíblia Sagrada. Essa iluminação direta é a responsável pelo surto de profetismo que tomou conta de Portugal com as profecias de Joaquim de Flora e Gonçalo Annes, o Bandarra, que se encontram na gênese do sebastianismo (Leonard, 1973). No Brasil, esse profetismo disseminou-se pelo sertão e fecundou a alma sertaneja.

“O Brasil povoou-se no século XVI, plantio das sementes humanas, seiva das primeiras raízes genealógicas. É o século de Bandarra, de D. Sebastião, nova floresta das profecias que haviam moldurado a eclosão do Mestre de Avis, início da eclíptica messiânica dos reis assinalados pelo Destino, desde Cruz de Ourique. Tempo do Povo de Gil Vicente e dos heróis de Luís de Camões. A religião no espírito popular, com a diluição moura, manteria a feição fatalista, astrológica, percebida nos lampejos proféticos, vizinhança de Deus, onde tudo era milagre" (Cascudo, 2002, p. 459).

Essa tradição parece ter sido disseminada pelo sertão, seja pelos cantadores, por intermédio dos pregadores, por meio dos profetas, seja pelas ladainhas dos beatos e santos, que até hoje povoam o imaginário sertanejo conforme documentado por Luís da Câmara Cascudo (2004, pp. 527-56).

"Bandarra aliou-se, desta forma, a uma tradição apocalíptica messiânica, presente no reino desde pelo menos a Lenda de Ourique, que perpassou autores como Fernão Lopes, Gil Vicente, Luís de Camões e Antônio Vieira, chegando até Fernando Pessoa. É por esse motivo que encontramos referências, nas Trovas, a elementos do Antigo Testamento, em especial aos profetas Isaías, Jeremias e Daniel, além de Esdras, presente apenas nas versões em vulgar da Bíblia" (Magalhães, 2004, p. 319).

O sebastianismo foi um movimento místico-secular que ocorreu em Portugal, na segunda metade do século XVI, como consequência da morte do rei $\mathrm{D}$. Sebastião na batalha de Alcácer-Quibir, em 1578 (Valensi, 1994). Em 4 de agosto daquele ano, na famosa batalha de Alcácer-Quibir, Portugal perdera seu rei de apenas 24 anos de idade, Dom Sebastião, morto sem deixar herdeiros, na maior catástrofe militar de sua história colonial. Por falta de herdeiros, o trono português terminou nas mãos do rei espanhol Felipe II. Apesar de o corpo do rei Dom Sebastião ter sido removido para 
Belém, o povo nunca aceitou o fato, divulgando a lenda de que o rei encontrava-se ainda vivo, em missão celestial, preparando umas miríades de anjos, num poderoso exército, esperando apenas o momento certo para volver ao trono e afastar o domínio estrangeiro (Godoy, 2009).

Esse mito foi construído a partir das necessidades da alma portuguesa de forjar seus heróis e da necessidade de autoafirmação de Portugal frente ao reino de Castela. O rei desaparecido na batalha de Alcácer-Quibir vai ganhando novos contornos e assume uma personalidade mítica no imaginário português: Dom Sebastião estava predestinado a salvar Portugal de todos os seus males.

"Apesar de ter sua imagem envolvida em casos embebidos em ações fraudulentas, Dom Sebastião ganhava maior potência no imaginário português: cada vez mais era tido como um rei desaparecido capaz de retornar a qualquer momento para trazer a salvação de Portugal" (Godoy, 2009, p. 24).

O maior divulgador dessa lenda foi o poeta popular Bandarra (Magalhães, 2004), que produziu incansáveis versos clamando pelo retorno do Desejado (Hermann, 1996). Explorando as crendices populares, vários oportunistas se apresentavam como o rei oculto na tentativa de obter benefícios pessoais. O sebastianismo tornou-se uma febre, até Fernando Pessoa adotou essa crença. $\mathrm{O}$ maior intelectual católico a aderir a esse movimento foi o padre Antônio Vieira.

"O discurso de Bandarra adquiriu características milenaristas à medida que apresentava elementos que favoreceriam a leitura em favor da constituição de um Quinto Império
Cristão, liderado pelo rei de Portugal, que converteria todos os povos do mundo e encaminharia a humanidade para um período de paz, antecessor do Juízo Final. Estes elementos, apresentados tanto pelas Trovas quanto pela literatura do período, fizeram de Bandarra profeta do sebastianismo e da Restauração Portuguesa, atendendo às expectativas de cristãos-novos e velhos, à medida que compartilhava a tradição profética lusitana marcada por influências ibéricas, joaquimitas, judaicas e pelo chamado messianismo português" (Magalhães, 2004, p. 319).

Em 1603, o nobre português Dom João de Castro, que lutava pela soberania do reino de Portugal, comenta, imprime e publica as trovas de Bandarra tornando, assim, públicas as crenças do profeta, poeta e sapateiro que acreditava na volta de Dom Sebastião como o monarca prometido de Portugal, que voltaria como o Desejado de Todas as Nações. Numa referência ao cumprimento da profecia bíblica de Ageu 2:7 - "E farei tremer todas as nações, e virá o Desejado de todas as nações, e encherei esta casa de glória, diz o Senhor dos Exércitos" -, Dom João de Castro foi encontrar, no discurso profético de Bandarra, a leitura que preenchia expectativas e crenças suas e do povo. A partir de sua interpretação, surge, enfim, um sebastianismo que ressalta contornos milenaristas, utópicos e escatológicos, transformando este texto na bíblia do sebastianismo, como bem observou João Lúcio de Azevedo em seu conhecido livro A evolução do sebastianismo (Godoy, 2009, p. 240).

Maria Isaura Pereira de Queiroz (1977, pp. 217-8) e Marcio Honório de Godoy (2009, p. 27) afirmam que as trovas de Bandarra foram divulgadas no Brasil. Registram esses autores que em 1591 Gregório Nunes foi 
denunciado pelo Tribunal do Santo Oficio na Bahia por esperar a vinda do messias prefigurado na pessoa do rei Dom Sebastião. Essas crenças influenciaram profundamente os movimentos messiânico-milenaristas brasileiros como Canudos, Contestado, Caldeirão e Pau de Colher (Queiroz, 1976; Galvão, 2009; Gomes, 2009; Menezes, 2009). Sobre a influência de Bandarra em Canudos, Euclides da Cunha escreveu:

"Esta justaposição histórica calca-se sobre três séculos. Mas é exata, completa, sem dobras. Imóvel o tempo sobre a rústica sociedade sertaneja, despeada do movimento geral da evolução humana, ela respira ainda na mesma atmosfera moral dos iluminados que encalçavam doidos, o Miguelinho ou Bandarra. Nem lhe falta para completar o símile, o misticismo político do sebastianismo. Extinto em Portugal, ele persiste todo, hoje, de modo singularmente impressionador, nos sertões do norte" (Cunha, 1979, p. 109).

Joaquim de Flora, por meio dos versos de Bandarra, influenciou o padre Antônio Vieira, especialmente em sua defesa perante o Tribunal do Santo Oficio. Essa defesa encontra-se publicada em dois volumes pela Universidade Federal da Bahia. Vieira influenciou, com seu pensamento, a construção do sonho messiânico brasileiro, como será demonstrado mais adiante.

\section{O SEBASTIANISMO DO PADRE ANTÔNIO VIEIRA}

O sebastianismo do padre Antônio Vieira aparece de modo claro nos Sermões de $\mathrm{Xa}$ vier dormindo e Xavier acordado, datados de 1694, na História do futuro, de 1718, e na Defesa perante o Tribunal do Santo Oficio. Vieira busca fundamentos bíblicos e teológicos para uma escatologia portuguesa. Em seus sermões proféticos, o império português é o reino escolhido por Deus para a manifestação do reino messiânico e o rei de Portugal, o messias escolhido.

"Os Sermões de Xavier dormindo foram frutos de uma reflexão mais consistente sobre o Quinto Império e também sobre a própria produção de Vieira, que compilava os seus escritos um tanto à margem dos acontecimentos metropolitanos. Ao contrário do Sermão do esposo, restringido à coroa portuguesa pelo passo restauracionista, podemos ver nos sermões sobre o 'Apóstolo do Oriente', espelho de um projeto profético bem delineado de alcance universal católico, liderado pela nação portuguesa, encabeçado pelo monarca, não mais necessariamente, D. João IV. Mais que isso, um futuro que dependeria da Companhia de Jesus, por meio de sua ação missionária e evangelizadora, reafirmando que esse Quinto Império, apesar de possuir dupla coroa temporal e espiritual, era o Reino de Cristo na Terra" (Lima, 2004, pp. 104-5).

Em 1662, Vieira fora expulso do Maranhão sob a acusação de proteger os índios. Foi desterrado para o Porto. O escrito, contudo, que lhe instaurou o processo inquisitorial, é a carta à rainha viúva $\mathrm{D}$. Luisa, enviada por intermédio do professor dela, seu irmão em religião, padre André Fernandes, bispo do Japão. Vieira, já no Sermão de São Roque, prometera a D. João IV o cetro do Quinto Império; pregando em Salvaterra em 1654, quando o rei já se encontrava adoecido de 
cuja cura todos esperavam! Cometera Vieira a imprudência de prometer no púlpito as consolações dadas à rainha - que o real enfermo não morreria, enquanto não cumprisse as profecias de Bandarra que o credenciavam para a grande missão de, pela vitória sobre os turcos, resgatar os lugares santos e fundar no mundo secular a Monarquia Universal de Cristo. Em novembro de 1656, morre, porém, o rei sem ver cumpridas as profecias de Vieira. Diante do inesperado, Vieira logo declara que o rei haveria de ressurgir dos mortos. Suas afirmações estão estribadas nas profecias de Bandarra (Vieira, 1957, p. 212, $\S 335)$. Pois se Bandarra havia acertado em tudo o mais, não haveria de errar nas visões que lhe mostraram D. João IV investido da divina missão de realizar na Terra as profecias bíblicas de Isaías e Daniel. Vieira prega tudo isso em São Luís do Maranhão em 1655 e envia para a rainha viúva as suas crenças em 1659 (Cidade, 1957; Vieira, 1957, p. 212, § 335).

Vieira foi mandado a Roma. Em fevereiro de 1663 , por ordem do Conselho Geral do Santo Ofício, o Tribunal de Coimbra recebe ordens para interrogar Vieira sobre o conteúdo da carta profética "A esperança de Portugal". Sofrendo de impaludismo, tuberculoso, alquebrado em seu corpo, não em sua fé, Vieira é preso pela Inquisição em 1665. O processo durou de 1663 a 1667. Na prisão conta apenas com a sua memória e uma pena para escrever a sua defesa contra os Autos sobre o papel que nesta cidade de Lisboa se divulgou no anno de 1160 sobre a ressurreição d'El Rey dom João $4^{\circ}$ tocantes ao Pe. Antônio Vieira relig ${ }^{o}$ da Companhia de Jesus preso no Cárcere do Custódio em 1. ${ }^{\circ}$ de outbr. ${ }^{\circ}$ de 1665. (sic) (Cidade, 1957, p. XXIII). Em sua defesa, Vieira apresenta a sua Representação dos motivos que tive para me parecerem prováveis de que se trata, dividida em duas partes (Cidade, 1957, p. 3; Vieira, 1957).

"Na presente representação procura Vieira fundamentar em promessas divinas a esperança em que comunga, de que tal restituição se efectuará. Era esta a última das nove proposições que, enviadas ao Santo Ofício de Roma para que as qualificasse, vieram de lá todas reprovadas. A 1., que afirma a futura existência do Quinto Império - estranha ao consenso geral dos Católicos, que tomam tal império como do Anticristo" (Cidade, 1957, pp. XIX-XXX).

O sebastianismo, por meio da tradição oral e da pregação de padre Antônio Vieira, propagou-se pelo Nordeste brasileiro e influenciou as crenças sertanejas sobre o fim do mundo e os movimentos messiânicos milenaristas como Canudos, Caldeirão e Pau de Colher. "Daí, entrando pelo século XIX e indo em frente, a figura de Dom Sebastião comparecerá em movimentos populares rebeldes e religiosos do sertão nordestino (Cidade do Paraíso Terreal, PE; Pedra Bonita, PE; Canudos, BA)" (Godoy, 2009, p. 30).

\section{MESSIANISMO SEBASTIANISTA NO SERTÃO BRASILEIRO}

Euclides da Cunha criou um retrato sombrio do Conselheiro como personagem trágico, guiado por forças obscuras, que o levaram à loucura e ao conflito com a Igreja e o governo. Enfatizou o caráter sebastianista e messiânico de Canudos, cujos habitantes acreditariam no retorno 
mágico do rei português D. Sebastião, desaparecido no século XVI, que voltaria para derrotar as forças da República e restaurar a monarquia eterna. Baseou sua prédica nos poemas populares e nas profecias apocalípticas, encontrados nas ruínas da cidade, que julgou refletirem a pregação de Conselheiro. Explicou, assim, alguns dos aspectos misteriosos da guerra, como a luta quase suicida dos conselheiristas, ou a migração para Canudos em pleno conflito. Sobre as relações entre o sebastianismo e as crenças da cidade de Canudos, Euclides da Cunha descreveu:

"Relataram-na depois, ingenuamente, os vencidos: Antônio Conselheiro seguira em viagem para o céu. Ao ver mortos os seus principais ajudantes e maior o número de soldados, resolvera dirigir-se diretamente à Providência. O Fantástico embaixador estava àquela hora junto de Deus. Deixara tudo prevenido. Assim é que os soldados, ainda quando caíssem nas maiores aperturas, não podiam sair do lugar em que se achavam. Nem mesmo para se irem embora, como das outras vezes. Estavam chumbados às trincheiras. Fazia-se mister que ali permanecessem para a expiação suprema, no próprio local dos seus crimes. Porque o profeta volveria em breve, entre milhões de arcanjos descendo - gládios flamívomos coruscando na altura numa revoada olímpica, caindo sobre os sitiantes, fulminando-os e começando o Dia do Juízo" (Cunha, 2002, pp. 711-2).

Esse sebastianismo de Canudos correu célere pelo sertão. Ainda hoje, em Juazeiro do Norte, quando um visitante chega à Igreja do Horto, local sagrado onde os romeiros do "Meu Padim Padi Ciço" esperam a ma- nifestação da parousia do seu messias, uma beata, paramentada, prostra-se à porta da igreja e canta uma música em que aparece claramente o messianismo sebastianista. "O padre Cícero não morreu, ele está no céu juntando uma legião de anjos para salvar o sofrido povo do sertão nordestino" (Lira Neto, 2009). Essa esperança messiânica na volta do padre Cícero Romão Batista revive na Igreja do Horto até os dias presentâneos. Na construção dessa igreja, os romeiros subiam a ladeira do Horto de joelhos e com uma pedra na cabeça. Acreditava-se que quando a construção da igreja estivesse construída, no ato da sua inauguração, o "Meu Padim Padi Ciço" voltaria do céu coberto de glória. Essa crença foi eternizada na voz de Luiz Gonzaga: "Olha lá, no alto do Horto, ele tá vivo, o Padim não está morto". O sebastianismo também serviu de substrato para o messianismo do Contestado (Menezes, 2009, p. 94).

Do século XV ao XVIII, Portugal assiste ao renascimento da literatura apocalíptica, com a pregação do iminente fim do mundo (Oliveira, 1997, pp. 103-11). Nessa pregação, a Missão abreviada assume um papel preponderante. Missão abreviada para despertar os pecadores e sustentar os fructos das missões, e destinado este livro para fazer oração e instrucções do povo, particularmente povo d' aldeia é o título de um livro do padre Manuel José Gonçalves Couto, editado em Portugal em 1859. Foi o livro mais editado no país durante o século XIX. É superior a 140 mil o número de exemplares que atingiu a tiragem das suas 16 edições, entre 1859 ( $1^{\mathrm{a}}$ edição) e 1904 (16 ${ }^{\mathrm{a}}$ edição). A Missão abreviada, além de uma tecnologia do misticismo, um manual de culto, é também uma apologia da fé ca- 
tólica e uma exposição rústica da doutrina das últimas coisas, uma escatologia precária!

"Jesus Cristo (diz o Santo Evangelho), falando dos sinais que haverão de preceder ao grande dia do juízo final, diz: 'Haverá sinais no sol, na lua, nas estrelas, e na terra opressão das gentes'. São horrorosos meus irmãos, os sinais que hão de preceder a segunda vinda de Jesus Cristo. Ele então há de vir como Juiz rigoroso e o mais terrível para castigar os pecadores que agora lhe negam o seu coração, nem cuidam na emenda do pecado. Fazei que estes sinais terríveis agora penetrem o vosso coração; deixai-vos dominar de um verdadeiro e santo temor da divina justiça; porque estando assim orientados, eu estou bem certo que deixareis todo o pecado, aborrecereis todas as vaidades do mundo e praticareis todas as virtudes" (Couto, 1859, pp. 149-50).

Na Missão abreviada, o paraíso é colorido, o inferno é dantesco. O castigo dos infiéis é descrito com cores negras do terror da Santa Inquisição. Aqueles que não aceitarem a pregação do padre Couto serão torturados por toda a eternidade no fogo do inferno pelo diabo e seus anjos. Os que tiverem melhor sorte irão para o purgatório, onde sofrerão padecimento igualmente terrível. Os que se converterem gozarão das delícias celestiais. A apologética escatológica não deixava escolhas para os camponeses: ou o céu, ou o inferno. Não havia meio-termo.

Depois que esses camponeses escolheram o céu, pelo estreito caminho da Missão abreviada, a Igreja deu-lhes as costas. Seja em Canudos, no Contestado, no Caldeirão, no Pau de Colher, a Missão abreviada forneceu o substrato religioso por meio da cultura oral para a construção de uma escatologia rústica do fim do mundo (Pompa, 2009, p. 73).

"Um dos moradores do Pau de Colher, José Senhorinho, adquiriu certo status, devido a algumas características (as mesmas que, em qualquer povoado ou lugarejo da caatinga, definem a posição de uma pessoa); tinha boas roças de mandioca, feijão e milho, mas, sobretudo, plantava e comerciava algodão e mamona, produtos de valor de exportação que, pelos padrões econômicos da região, conferiam-lhe uma certa segurança financeira. Único da família, Senhorinho sabia ler e gostava de ler a Bíblia, a Missão abreviada e o Caminho recto; era também rezador, conhecia rezas para curar dores e em sua casa havia festejos" (Pompa, 2009, pp. 72-3).

\section{O PADRE IBIAPINA}

No século XIX, padre Ibiapina foi o mestre dos sertanejos do Nordeste. Padre e Mestre eram o seu nome. Quando ainda não havia caminhos, nem cidades, nem organização social ou política no interior do Nordeste, padre Ibiapina foi capaz de transmitir uma sabedoria simples, rude, exigente e adaptada às necessidades dessa população. Em muitos lugares do Nordeste ainda se conservam fervorosamente práticas e devoções apregoadas há mais de cem anos pelo grande missionário (Comblin, 1984).

José Antônio Pereira Ibiapina, natural da Vila de Sobral, nasceu em 5 de agosto de 1806, o terceiro filho do casal Teresa Maria de Jesus e Francisco Miguel Pereira. Sua família se transfere para a vila de Icó e Ibiapina em 1816. Nesse mesmo ano matricula-se na escola do professor José Fe- 
lipe. Em 1817, seu pai o envia para a Vila do Jardim a fim de estudar latim com o latinista Joaquim Teotônio Sobreira de Melo. Sua família finalmente se transfere para Fortaleza em 1823. Esse ano marcará a vida de Ibiapina, posto que morre sua mãe e ingressa no Seminário de Olinda, onde estuda por um período (Comblin, 1984).

Após três anos de meditação e reflexão, Ibiapina decide-se pelo sacerdócio. Nesse sentido, em 12 de julho de 1853, aos 47 anos de idade, ele se torna padre Ibiapina. Logo após sua ordenação, o bispo Dom João da Purificação o nomeia vigário geral e provedor do Bispado e professor de Eloquência do Seminário de Olinda; contudo, opta pela vida missionária.

A paixão missionária do padre Ibiapina é a compaixão pelos pobres. Padre Ibiapina angariava donativos. Dinheiro, cereais, animais, tijolo e madeira eram oferecidos espontaneamente. Tudo para minorar o sofrimento dos mais despossuídos. Sua dedicação e consagração pessoal aos pobres atraíram a simpatia de muita gente que trabalhava sem remuneração nas obras de caridade. $\mathrm{Na}$ década de 1860, o padre Ibiapina realizava a construção de casas de caridade na Paraíba, Rio Grande do Norte e Ceará. Em outubro de 1862, passava por Acaraú, onde granjeava fama de santo. Em 1865, inaugurava a casa de caridade de Missão Velha. Em 1868 e 1869, fundava cemitérios, capelas, igrejas e construía açudes em Barbalha e Milagres. Nas cidades, vilas e povoados do sertão era sempre recebido debaixo de aclamações e flores, ao som de música e ao pipocar dos rojões. Entrava sempre acompanhado de cavaleiros que iam esperá-lo às portas das localidades. A respeito das missões do padre Ibiapina, assim se expressava o jornal
Cearense, de 4/8/1868: "Suas missões foram fecundas em resultados benéficos. Conseguiu que inimigos se reconciliassem, fez chegar ao tribunal da penitência muitas ovelhas que viviam desgarradas do rebanho, vários casamentos se fizeram de pessoas que persistiam no pecado da incontinência”. Correspondência do Crato, publicada em Cearense, em 1869, comparava o missionário ao Anjo da Providência na casa de Ló. Não são poucos os milagres do padre Ibiapina narrados por Montenegro (1959, pp. 16-21).

A influência do padre Ibiapina correrá também na ordenação de beatos e beatas, na organização das ordens dos penitentes e na manutenção das casas de caridade, onde esses santos populares iriam viver futuramente. Esses beatos e as ordens de penitentes serão a base hierárquica do messianismo de Canudos, Caldeirão e Pau de Colher, dentre outros.

\section{CONSIDERAÇÕES FINAIS}

Os termos "messias" e "messianismo" encontram-se incorporados a diversas linguagens: jornalística, científica, religiosa e mesmo coloquial. São termos utilizados na fala da vida cotidiana. Messias é empregado quase sempre para se referir aos eventos que têm como base da metáfora a figura de um personagem carismático e vitorioso. Já messianismo consiste num fenômeno recorrente, complexo e multifacetado cuja origem é, sem dúvida, o messias. No judaísmo e no cristianismo, a raiz desse evento prende-se ao messias; no mundo greco-romano, ao mito do herói. Seja o messias ou o herói, o processo histórico-sociológico e psicológico desencadeado apresenta-se com algumas 
variáveis semelhantes. Quais as fontes desse messianismo no Brasil? Esta pesquisa buscou revistar essas fontes e acrescentar pelo menos mais duas: a Missão abreviada e a obra religiosa e social do padre Ibiapina.

$\mathrm{O}$ primeiro estudioso que delineou as origens sociais da religiosidade de massa no Brasil foi o sociólogo Rui Facó (1976). Na obra Cangaceiros e fanáticos, ele traça a árvore genealógica da miséria no Brasil a partir da libertação dos escravos em 1888, quando esses foram alforriados e ao mesmo tempo substituídos pelos imigrantes europeus. A substituição dos escravos pela mão de obra assalariada importada de outros países deixou os ex-escravos na situação da mais absoluta miséria, pois receberam uma liberdade relativa e condicionada pelo abandono econômico e social, cujo desfecho foi o empobrecimento. A liberdade do escravo não incluía emprego, moradia ou mesmo o alimento para si e para a sua família. Rui Facó (1976) afirma que esses libertos ficavam, então, até mesmo sem os recursos básicos da economia necessários para uma subsistência precária. Vagavam pelos campos, povoados, vilas e cidades onde quase sempre eram considerados indesejáveis e recebidos à bala. À semelhança de Maria
Isaura Pereira de Queiroz (1976), Facó explica as origens dos movimentos religiosos brasileiros considerando apenas a variável econômica e as condições sociais dos seus adeptos (Facó, 1976, p. 29).

Já o autor deste texto partiu da premissa de que a variável econômica, embora relevante por si só, não é suficiente para explicar a complexidade desses movimentos que têm suas raízes na alma religiosa e mítica do povo português e brasileiro.

A estrutura complexa do messianismo amplia o espaço caudal de fontes em que se deve buscar suas origens. No Brasil, o manancial de fontes messiânicas é igualmente imenso: o judaísmo antigo, no Velho Testamento; o cristianismo primitivo, no Novo Testamento; o mito indígena da Terra sem Males; o catolicismo ultramontano com as contribuições de Joaquim de Flora e de Gonçalo Annes, o Bandarra; o sebastianismo; o sonho escatológico do padre Antônio Vieira; o catolicismo popular da Missão abreviada; a obra piedosa do padre Ibiapina, etc. A partir dessas contribuições, este artigo analisou as fontes do messianismo brasileiro e traçou a árvore genealógica mítica e religiosa desses movimentos, mormente no Nordeste do Brasil. 


\section{BIBLIOGRAFIA}

AQUINO, Rubim Santos Leão de. "A pedra da morte", in Cristiane Costa. Nossa história. Fé e luta - movimentos messiânicos que incendiaram o Brasil. São Paulo, Editora Vera Cruz, 2006, pp. 18-22.

BASTIDE, Roger. "Prefácio da 2a edição", in Maria Isaura Pereira de Queiroz.

O messianismo no Brasil e no mundo. São Paulo, Alfa Ômega, 1976.

BRITO, Eleanora Zicari Costa de. "A santa ressuscitada de Goiás", in Cristiane Costa. Nossa história. Fé e luta - movimentos messiânicos que incendiaram o Brasil. São Paulo, Editora Vera Cruz, 2006.

CARNEIRO; MARTINS. Os Aves de Jesus em Juazeiro do Norte. 2006.

CASCUDO, Luiz da Câmara. Superstição no Brasil. Belo Horizonte/São Paulo, Itatiaia/ Edusp, 1985.

CASTRO, Josué de. Documentário do Nordeste. 3a ed. São Paulo, Brasiliense, 1965. Geografia da fome. São Paulo, Brasiliense, s.d.

Ensaios de geografia humana. São Paulo, Brasiliense, s.d.

CIDADE, Hernani. "Introdução" e "Notas", in Antônio Vieira. Defesa perante o Tribunal do Santo Ofício. Salvador, Aguiar e Souza/Livraria Progresso, 1957.

COMBLIN, José. Instruções espirituais do padre Ibiapina. São Paulo, Paulus, 1984.

COUTO, Manuel José Gonçalves. Missão abreviada para despertar os descuidados, converter os pecadores e sustentar o fruto das missões. Porto, 1859.

CUNHA, Euclides da. Os sertões: campanha de Canudos. Rio de Janeiro, Edições de Ouro, 1966.

DESROCHE, Henri. Sociologia da esperança. Trad. Jean Briant. São Paulo, Edições Paulinas, 1985.

DOBRORUKA, Vicente. Considerações sobre o pensamento trinitário de Joaquim de Fiore.

Disponível em: http://www.pejunb.org/downloads/art_joaquim.pdf. Acesso em: 1\% mar./2009.

FACÓ, Rui. Cangaceiros e fanáticos. 4ª ed. Rio de Janeiro, Civilização Brasileira, 1976.

FRANCO, José Eduardo; MOURÃO, José Augusto. Influência de Joaquim de Flora em Portugal e na Europa nos escritos de Natália Correia sobre a utopia da idade feminina do Espírito Santo. Lisboa, Roma Editora, 2005.

GALVÃO, Walnice Nogueira. "Euclides da Cunha, precursor", in Revista USP, 82. São Paulo, CCS-USP, jun.-jul.-ago./2009.

HERMANN, Jacqueline. "As trovas de Gonçalo Annes Bandarra (Portugal, século XVI): notas para a abordagem de uma fonte", in Ilana Blaj; John Monteiro. História \& utopias. São Paulo, ANPUH/CNPq, 1996.

GODOY, Márcio Honório de. "O desejado e o encoberto: potências de movimentos de um mito andarilho", in Revista USP, 82. São Paulo, CCS-USP, jun.jul.-ago./2009.

GOMES, Antônio Maspoli de Araújo. "A destruição da terra sem males: o conflito religioso do Caldeirão de Santa Cruz do Deserto", in Revista USP, 82. São Paulo, CCS-USP, jun.-jul.-ago./2009.

LEONARD, Émile-G. L'lluminisme dans un protestantisme de constitution récente (Brésil). Paris, P.U.F., 1973.

LIMA, Luís Felipe Silvério. Padre Vieira: sonhos proféticos, profecias oníricas. O tempo do Quinto Império nos Sermões de Xavier dormindo. São Paulo, Humanitas, 2004. 
MONTENEGRO, Abelardo Fernando. História do fanatismo religioso no Ceará. Fortaleza, Editora A Batista Fontenele, 1959.

NETO, Lira. Padre Cícero: Poder, fé e guerra no sertão. São Paulo, Companhia das Letras, 2009. LOPES, Francisco Régis. Caldeirão. Fortaleza, Eduece, 1991.

LÖWITH, Karl. O sentido da história. Lisboa, Edições 70, 1991.

MACHADO, Paulo Pinheiro. "Canudos do sul", in Cristiane Costa. Nossa história. Fé e lutamovimentos messiânicos que incendiaram o Brasil. São Paulo, Editora Vera Cruz, 2006.

MAGALHÃES, Leandro Henrique. Poder e sociedade no reino de Portugal, século XVI: as trovas de Bandarra. Tese de doutorado. Universidade Federal do Paraná, 2004.

MARTINS, Cláudia Mentz. "Os fiéis armados de Jacobina", in Cristiane Costa. Nossa história. Fé e luta - movimentos messiânicos que incendiaram o Brasil. São Paulo, Editora Vera Cruz, 2006.

MENEZES, Celso Vianna Bezerra de. "Rituais de devoção: os herdeiros do milenarismo do Contestado", in Revista USP, 82. São Paulo, CCS-USP, jun.-jul.-ago./2009.

MONTEIRO, Douglas Teixeira. "Um confronto entre Juazeiro, Canudos e Contestado", in Fausto Boris (dir.). História geral da civilização. Tomo III - O Brasil Republicano - $2^{\circ}$ volume: Sociedade e instituições - 1889-1930. Rio de Janeiro/São Paulo, Difel, 1977. Os errantes do Novo Século: um estudo sobre o surto milenarista do Contestado. São Paulo, Livraria Duas Cidades, 1974.

NEGRÃO, Lísias Nogueira. "Sobre os messianismos e milenarismos brasileiros", in Revista USP, 82. São Paulo, CCS-USP, jun.-jul.-ago./2009.

OLIVEIRA, Maria Gabriela Gomes. "Horrores breves, horrores eternos. Uma reflexão sobre a obra Gritos do inferno para despertar ao mundo do padre Joseph Boneta", in Os "últimos fins" na cultura ibérica dos sécs. XV a XVIII. Porto, Faculdade de Letras do Porto/Instituto de Cultura Portuguesa, 1997.

POMPA, Cristina. "Memórias do fim do mundo: o movimento de Pau de Colher", in Revista USP, 82. São Paulo, CCS-USP, jun.-jul.-ago./2009.

QUEIROZ, Maria Isaura Pereira de. O messianismo no Brasil e no mundo. 2a ed. São Paulo, Alfa Ômega, 1976.

QUEIROZ, Renato da Silva. A caminho do paraíso, o surto messiânico-milenarista do Catulé. São Paulo, FFLCH/USP-CER, 1995.

O demônio e o messias: notas sobre o surto sociorreligioso do Catulé", in Revista USP, 82. São Paulo, CCS-USP, jun.-jul.-ago./2009.

REGO, José Lins do. Pedra Bonita. 2a ed. Rio de Janeiro, Livraria José Olympio Editora, 1939.

RODRIGUES, R. N. Os africanos no Brasil. Brasília, UNB, 2006.

SOUSA, Rodrigo Franklin. "O desenvolvimento histórico do messianismo no judaísmo antigo: diversidade e coerência", in Revista USP, 82. São Paulo, CCS-USP, jun.-jul.ago./2009.

VALENSI, Lucette. Fábulas da memória. A batalha de Alcácer-Quibir e o mito do sebastianismo. Trad. Maria Helena Franco Martins. Rio de Janeiro, Nova Fronteira, 1994.

VAN GRONINGEN, Gerard. Revelação messiânica no Antigo Testamento, a origem divina do conceito messiânico e seu desdobramento progressivo. $2^{\mathrm{a}} \mathrm{ed}$. Trad. Cláudio Wagner. São Paulo, Cultura Cristã, 2003.

VIEIRA, Pe. Antônio. Defesa perante o Tribunal do Santo Ofício. Introdução e notas de Hernani Cidade. Salvador, Aguiar e Souza/Livraria Progresso, 1957. 